This is the accepted manuscript version of the paper:

Eszter Békési, Bálint Süle, László Lenkey, Ágnes Bőgér, and István Bondar

Double-difference relocation of the 29 January 2011 ML 4.5 Oroszlány earthquake and its aftershocks and its relevance to the rheology of the lithosphere and geothermal prospectivity ACTA GEODAETICA ET GEOPHYSICA 52: pp. 229-242. (2017)

DOI 10.1007/s40328-017-0195-7

The final publication is available at link.springer.com:

https://link.springer.com/article/10.1007/s40328-017-0195-7 


\title{
Double-difference location of the 29 January 2011 ML 4.5 Oroszlány earthquake and its aftershocks and its relevance to the rheology of the lithosphere and geothermal prospectivity
}

\author{
Eszter Békési ${ }^{1}$, Bálint Süle², László Lenkey ${ }^{3}$, Ágnes Bőgér ${ }^{4}$, and István Bondar² \\ ${ }^{1}$ TNO Utrecht, Netherlands \\ ${ }^{2}$ Kövesligethy Radó Seismological Observatory ,Geodetic and Geophysical Institute, Research Centre for \\ Astronomy and Earth Sciences, Hungarian Academy of Sciences (MTA CSFK GGI KRSZO) \\ ${ }^{3}$ Department of Geophysics and Space Science, Institute of Geography and Earth Sciences Eötvös Loránd \\ University \\ ${ }^{4}$ MOL Budapest, Hungary
}

\begin{abstract}
In the central part of Hungary, an earthquake with the local magnitude of 4.5 occurred near the town of Oroszlány, on 29 January 2011. The main shock and its more than 200 aftershocks were recorded by a significant number of three-component seismic stations, which enabled us to perform multiple event location on the event cluster. We applied the double difference, HypoDD method to relocate the aftershock sequence in order to identify the pattern of active faulting. We used the extended ISC (International Seismological Centre) location algorithm, iLoc to determine the initial single event locations for the aftershock sequence and applied multiple event location algorithm on the new hypocenters. To improve both location precision and accuracy, we added differential times from waveform cross correlation to the double-difference multiple event location process to increase the accuracy of arrival time readings.

We show that both HypoDD collapses the initial, rather diffuse locations into a smaller cluster and the vertical cross-sections show sharp images of seismicity. Some of the relocated events in the cluster are ground truth quality with a location accuracy of $5 \mathrm{~km}$ or better. Having achieved accurate locations, we further examined the extent of the seismogenic zone. We investigated the relationship between geothermics and seismicity through strength profiles constructed for the study area. The aftershocks of the Oroszlány earthquake are dominantly in the range of 5 to $10 \mathrm{~km}$, fitting well to the extent of the thin brittle part of the crust. It shows that the events are well in accordance with a thermally attenuated lithosphere and elevated geothermal gradient in the upper crust and basin sediments. These findings underline the geothermal prospectivity of the Panonian Basin.
\end{abstract}

\section{Introduction}

Accurate earthquake hypocenter determination is crucial to understand tectonic processes such as identifying active structures in the Earth's crust. Accurate event location also gained importance in imaging of underground industrial processes for instance hydraulic fracturing or reservoir monitoring. Errors in earthquake location can be significantly reduced by adapting multiple event location methods, which means the simultaneous analysis of arrival times belonging to the same event cluster. Seismicity in the central part of the Pannonian basin is moderate. Earthquake hypocenters are mostly located in the upper part of the crust. Focal mechanism solutions indicate dominantly thrust and strikeslip faulting, but normal faulting also occurs in the in area (Tóth et al. 2008). Several regions of Hungary can be characterized by higher likelihood of earthquake occurrence, with large magnitude events in the last centuries (Figure 1.). According to statistical analysis, four to five earthquakes with a magnitude between 2.5 to 3.5 are expected annually in the country. Events causing light damage may occur every 15-20 years, and the expected recurrence of stronger earthquakes (with magnitude of 5.56) is about $40-50$ years (Tóth et al. 2002). 
Neotectonic activity in the Pannonian basin is controlled by the counterclockwise rotation of the Adriatic microplate relative to Europe (Adria push) and the complex geometry of the surrounding orogenic belts (Bada et al. 2007). The central-eastern Transdanubian Range accumulates the differential northeastern motion of 1-1.3 mm/year (Grenerczy et al. 2000), characterized by many poorly constrained structural elements (Fodor et al. 2005). The area is also the seismically most active region of the country, where four significant earthquakes originated in the last 250 years (Figure 1.).

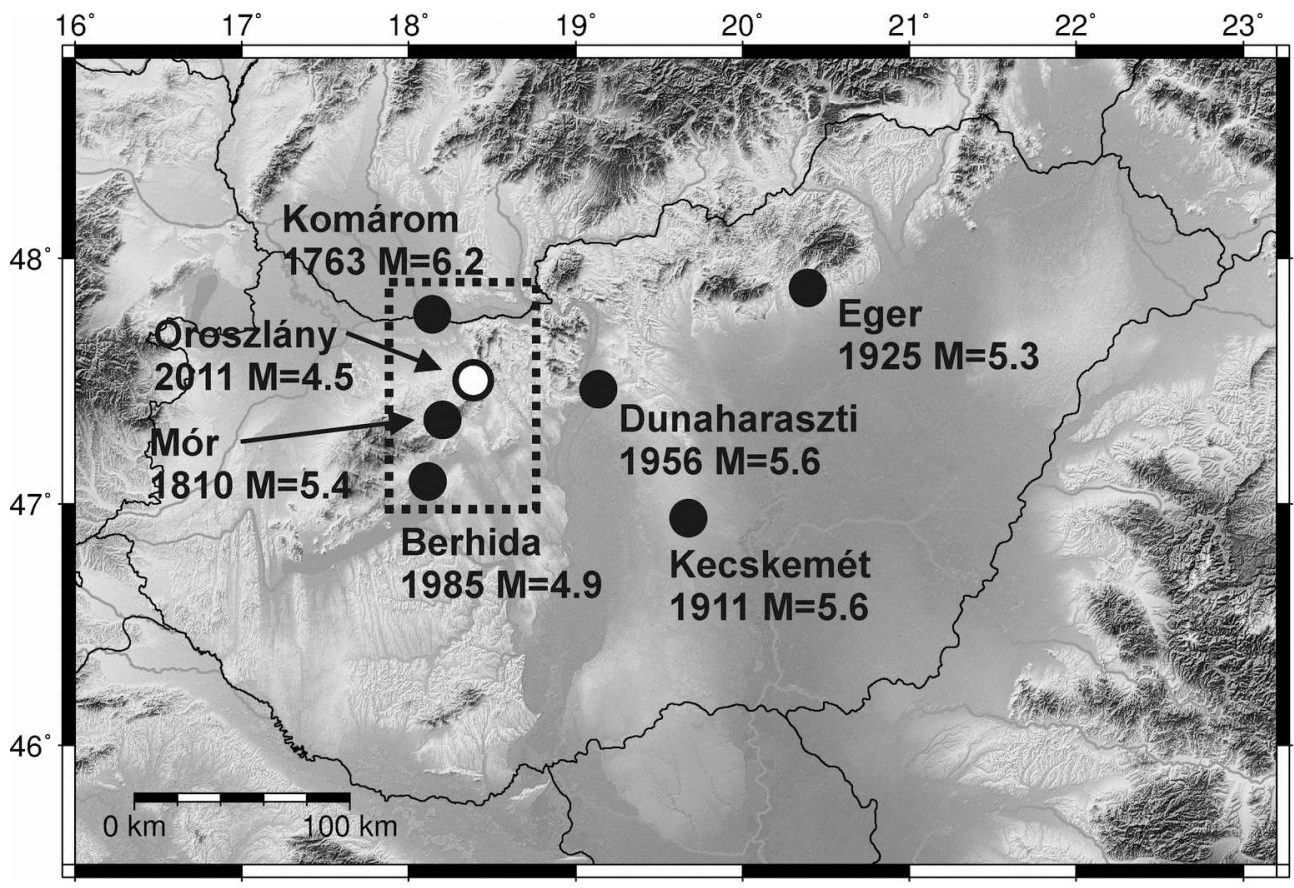

Figure 1. Map showing the most significant earthquakes occurred in Hungary. The seismically most active Berhida-Mór-Komárom region, where the Oroszlány earthquake (white circle) originated, is outlined with dotted black rectangle.

In the seismically most active Berhida-Mór-Komárom region, an earthquake with the local magnitude of 4.5 occurred on 29 January 2011. The mainshock was followed by more than 200 aftershocks, but only four of them exceeded the local magnitude of 2.0. Moment tensor solutions of the five largest magnitude earthquakes show NE-SW maximal horizontal stress axes (Wéber and Süle 2014), fitting well into the regional stress field of the Pannonian basin (Bada et al. 2007).

In this paper we present the results of the multiple event location analysis on the 2011 Oroszlány, Hungary aftershock sequence. Prior to the multiple event location, earthquakes reported in the Hungarian National Seismological Bulletin were relocated with the extended ISC location algorithm, iLoc (Bondár and Storchak 2011). We added both P and S differential times from waveform crosscorrelation to the double-difference relocation. Having achieved accurate locations for the event cluster, we are able to identify the location of the active fault related to the seismicity.

It is well-known that geothermal conditions have strong influence on the seismicity through the rheology of the litosphere. Elevated temperatures and heat flow in the Pannonian basin suggest that the transition from brittle to ductile deformation is in relatively shallow depth. The distribution of the focal depths indicates that mostly shallow earthquakes occur in Hungary, in good agreement with the thin brittle part of the crust (e.g. Lenkey et al. 2002). The improved depth resolution of the aftershock sequence enables us to investigate the strength of the lithosphere in the study area.

\section{Seismic network and data used in the study}

We performed the relocation process on earthquakes located within the $20 \mathrm{~km}$ radius of the Oroszlány mainshock recorded between 29 January 2011 and 1 June 2011. Figure 2. shows the seismic stations 
located within the 3-degree radius of the mainshock that registered any of the aftershocks. These stations were selected to obtain both $\mathrm{P}$ and $\mathrm{S}$ arrival times for the single event location. For the multiple event location, only waveforms from stations located closer to the cluster were collected to obtain more accurate locations.

Seventeen of the total fifty-five stations are located in Hungary. The Hungarian National Seismological Network (HNSN, doi:10.14470/UH028726, 1995) operated by the Kövesligethy Radó Seismological Observatory (KRSO) comprised six permanent broadband stations and two short-period ones. Data were also available from the seven short-period stations of the Paks Microseismic Monitoring Network (PMMN). Two days after the mainshock, on the 1st of February, two temporary stations, Bokod (BOKD) and Vértessomló (VSOM) were deployed near the earthquake by the KRSO to improve station geometry for recording the aftershocks. These two stations were in operation until 13 April, 2011.
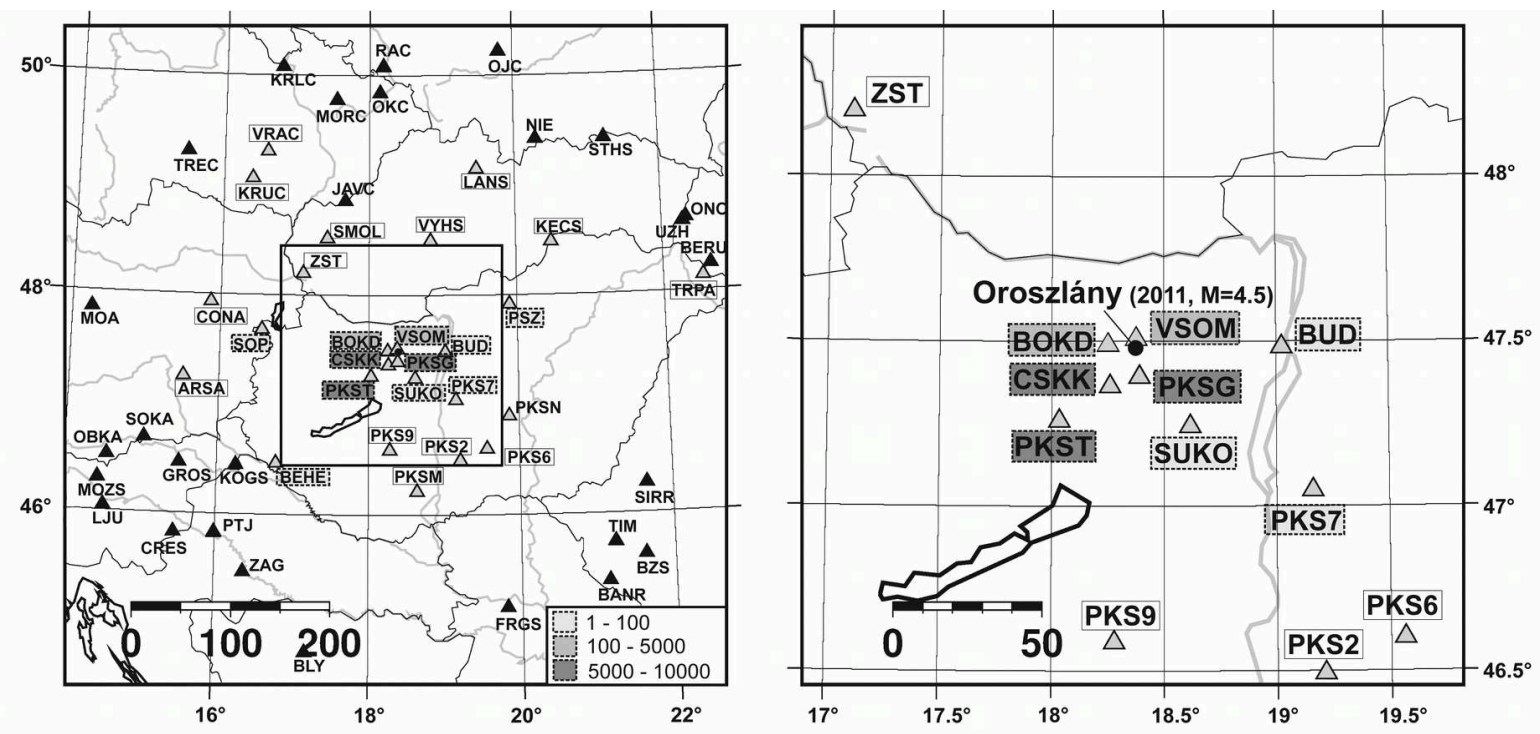

Figure 2. Seismic stations located in the 3-degree radius (left) and 1-degree radius (right) of the mainshock. Grey triangles are stations used for the multiple event location. Station codes in boxes indicate stations used for HypoDD relocations with catalog dataset (solid black boxes, 23 stations), both catalog and cross-correlation data (dashed black boxes, 8 stations). Black circle indicate the location of Oroszlány earthquake and its aftershocks. Stations where cross-correlation differential times are available are shaded according to the number of cross-correlation observations.

\section{Quality control}

Before the relocation process, we performed quality control on the dataset to eliminate events with unreliable locations. The quality of a solution depends on the spatial distribution of the seismic stations described by the azimuthal gap values. The primary azimuthal gap is measured as the largest open azimuth between recording stations. The secondary azimuthal gap, defined as the largest azimuthal gap filled by a single station, provides a better metrics on station coverage and sensitivity to picking errors (Bondár et al. 2004). Thus, we considered event locations with a secondary azimuthal gap larger than $315^{\circ}$ as unreliable solutions, and excluded from further analysis.

\section{Single event location}

A new location algorithm developed at the ISC (Bondár and Storchak 2011) was applied to determine the initial absolute locations of the aftershock sequence before executing the multiple event locations. The iLoc locator performs iterative linearized inversion using a priori estimate of the data covariance matrix (Bondár and McLaughlin 2009) to account for correlated model errors. To obtain initial hypocenter guess, a non-linear grid search algorithm (Sambridge and Kennett 2001) is conducted to 
avoid that the linearized location algorithm get stuck in a local minimum of the arrival time misfit function.

A recent study investigating the Oroszlány aftershocks (Wéber and Süle 2014) selected 68 events with high quality arrival-time data by manually repicking $\mathrm{P}$ and $\mathrm{S}$ arrivals. These phase picks are considered more precise than the original bulletin readings, therefore they were introduced to replace bulletin arrival time data for the event location iLoc. ILoc relocations were performed with a local 1D velocity model (Gráczer model (Gráczer and Wéber 2012), Table 1.). Bulletin and iLoc locations are shown in Figure 3.. On the bulletin map events originated before the two temporary stations VSOM and BOKD were deployed (black circles) are separated from the ones determined with the improved station coverage (grey circles). This location bias is the consequence of the absence of stations in the eastern direction. ILoc hypocenters obtained using the Gráczer model (Figure 3., second column) seem to be adequate initial locations for events occurred both before and after the deployment of the two permanent stations.

\section{Waveform cross-correlation}

Waveform cross-correlation of the seismograms was performed to derive more accurate locations of the aftershock sequence. Waveforms from stations nearby the cluster (Figure 2.) were correlated, since the aftershocks have small magnitudes, and thus have reasonable signal-to-noise ratio only at close distances. Before the cross-correlation, the amplitude spectra of the waveforms were inspected to determine the frequency domain of the signal. According to the spectra, we applied a Butterworth filter between $0.8-10 \mathrm{~Hz}$ and $0.8-6 \mathrm{~Hz}$ for $\mathrm{P}$ and $\mathrm{S}$ waves, respectively. The time windows were determined by the first $\mathrm{P}$ and $\mathrm{S}$ predicted travel-times with respect to iLoc locations. Different windows were cut from the waveforms depending on the station distances to separate $\mathrm{P}$ and $\mathrm{S}$ first arrivals. P and S cross-correlations were calculated from the vertical and the eastern components of seismograms, respectively. We discarded correlation coefficients below 0.6 ensuring smaller, but higher quality dataset for the multiple event location process. A threshold for lag with $0.8 \mathrm{~s}$ was also introduced to eliminate potential false correlations or cycle skippings.

\section{Double-difference relocation}

The method we used for multiple event location is the double-difference algorithm, HypoDD (Waldhauser and Ellsworth 2000). The double-difference method combines observed and theoretical travel-time differences as their residuals (double differences) are minimized for pairs of earthquakes at each station for all observed event pairs. The main assumption of the method is that if two events originate relatively close to each other, the waves propagate through the same ray paths except for the source region. Therefore, the difference between the travel times can be associated with the spatial offset between the events. The new locations are determined by iteratively solving the doubledifference equation in a weighted least-squares sense for all hypocenter pairs at all stations. Both ordinary absolute travel-time measurements and cross-correlation P-and S-wave differential traveltime measurements are suitable for the calculations. The a priori weights may be recomputed according to the misfit during the inversion and the offset between the events.

We applied HypoDD on iLoc initial locations using the combination of bulletin and cross-correlation differential times. We adapted different weighting schemes during the iterations. We first downweighted the cross-correlation data to ensure that bulletin data control the large scale picture. Then, for the further iterations, cross-correlation data were strongly weighted in order to refine the locations of event pairs having cross-correlation measurements. We applied the local 1D-layered P-wave velocity model (Gráczer and Wéber 2012) with the parameters reported in Table 1. to solve the system of double-difference equations.

\begin{tabular}{|c|c|c|c|c|}
\hline & Layer 1 & Layer 2 & Layer 3 & Layer 4 \\
\hline $\begin{array}{c}\text { Depths of top } \\
\text { of layer [km] }\end{array}$ & 0.0 & 3.0 & 19.0 & 26.0 \\
\hline
\end{tabular}




\begin{tabular}{|c|c|c|c|c|}
\hline $\begin{array}{c}\text { Layer velocities } \\
\text { of } \mathbf{P -} \\
\text { waves[km/s] }\end{array}$ & 5.30 & 5.74 & 6.29 & 7.93 \\
\hline
\end{tabular}

Table 1. Layer thicknesses and P-wave velocities after Gráczer and Wéber (2012). The Swave velocities were calculated using $v_{p} / v_{s}=1.74$ ratio.

\section{Results of the double-difference relocations}

Hereby we present the results of the HypoDD relocations on the iLoc initial locations. The number of relocated events is lower than the initial hypocenters, as a result of events may be descarded during the relocation process.

Results show that HypoDD hypocenters are collapsed to a smaller cluster (Figure 3.). The relocated earthquakes show a vertical trend on both sections, the picture of seismicity becomes more focused. The epicenters indicate a slightly W-E trending pattern, but the W-E section suggests that it is just the consequence of the steeply eastward dipping cluster. The main shock is located about $1 \mathrm{~km}$ Northern from the centroid of the aftershock sequence, but becomes closer to the cluster than the initial iLoc location. The cross-correlation dataset ensures improved depth resolution. Most of the events are located between 5 and $10 \mathrm{~km}$ depth, except for a few events, where no cross-correlation measurements were available. On the S-W sections, a steeply southward dipping trend can be identified, explained most likely by the uncertain locations of the inverse triangles. The absolute location of the relocated cluster is shifted towards North relative to the bulletin locations, suggesting that the position of the cluster centroid is controlled by the initial solution. 

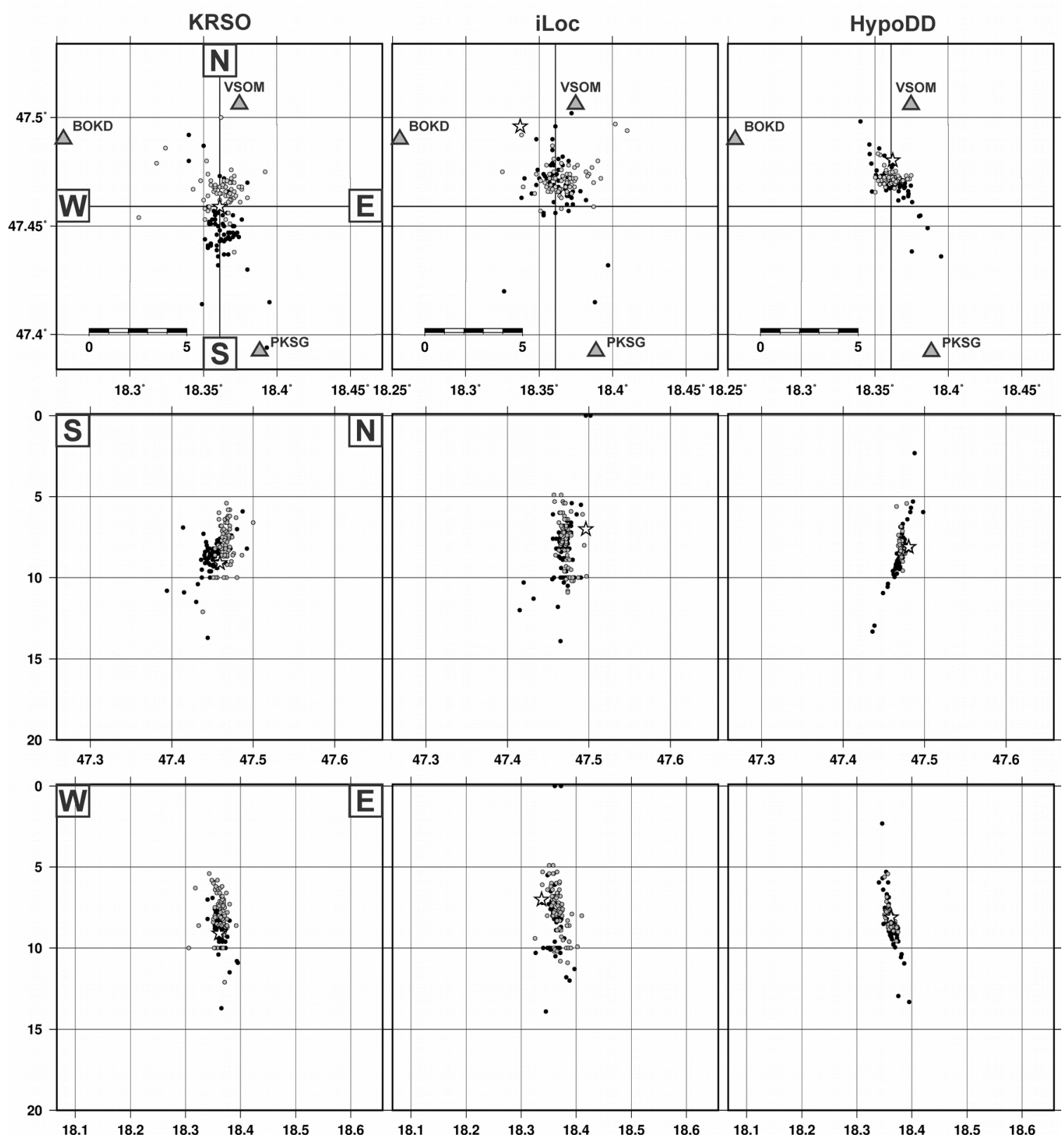

Figure 3. Map views (upper), S-N sections (middle) and W-E sections (bottom) of hypocenters reported in the KRSO bulletin (first column), iLoc relocations (second column), and HypoDD results (third column) on iLoc initial locations. The main shock is indicated with a star. Black and grey circles are events occurred before and after BOKD and VSOM were deployed, respectively.

\section{Ground truth events}

We assessed the location accuracy of the earthquakes located with iLoc. Seven of the events fulfil the epicentre accuracy criteria (Bondár et al. 2004) with a location accuracy of $5 \mathrm{~km}$ or better (Table 2.). These ground truth events fix the absolute positions of the cluster suggesting that the whole aftershock sequence has ground truth quality. The spatial offset between the ground truth events before and after the relocation is less than $5 \mathrm{~km}$, therefore the entire cluster can be promoted to GT5.

\begin{tabular}{|c|c|c|c|c|}
\hline Origin time $[\mathrm{s}]$ & Latitude $\left[^{\circ}\right]$ & $\begin{array}{c}\text { Longitude } \\
{\left[{ }^{\circ}\right]}\end{array}$ & $\begin{array}{c}\text { Depth } \\
{[\mathrm{km}]}\end{array}$ & $\begin{array}{c}\text { Spatial offset between iLoc } \\
\text { and HypoDD hypocenters } \\
{[\mathrm{km}]}\end{array}$ \\
\hline
\end{tabular}




\begin{tabular}{|c|c|c|c|c|}
\hline $\begin{array}{c}20: 58: 45.604 \\
30-01-2011\end{array}$ & 47.456 & 18.330 & 6.8 & 3.301 \\
\hline $\begin{array}{c}20: 29: 10.019 \\
16-02-2011\end{array}$ & 47.457 & 18.350 & 4.6 & 4.099 \\
\hline $\begin{array}{c}21: 48: 40.310 \\
16-02-2011\end{array}$ & 47.473 & 18.374 & 9.3 & 0.955 \\
\hline $\begin{array}{c}22: 25: 02.616 \\
16-02-2011\end{array}$ & 47.470 & 18.375 & 8.1 & 0.592 \\
\hline $\begin{array}{c}01: 45: 23.408 \\
11-03-2011\end{array}$ & 47.474 & 18.324 & 9.3 & 2.929 \\
\hline $\begin{array}{c}02: 42: 00.887 \\
12-03-2011\end{array}$ & 47.462 & 18.359 & 10.3 & 3.311 \\
\hline $\begin{array}{c}23: 41: 31.832 \\
05-04-2011\end{array}$ & 47.494 & 18.410 & 8.0 & 3.829 \\
\hline
\end{tabular}

Table 2. List of the hypocenters of the ground truth events from the iLoc cluster and their spatial offset compared to HypoDD hypocenters.

\section{Related focal mechanism and fault data}

Achiving accurate locations for the event cluster, we interpreted our results in the framework of the fault geometry and the mapped faults of the study area. According to moment tensor solutions of a recent study (Wéber et al., 2014), the mainshock and three of the aftershocks has a strike-slip mechanism with a reverse component. The moment tensor solutions show either right lateral slip on a North-South-striking, or left-lateral movement on an East-West striking nodal plane (Figure 4.). To resolve the fault plane ambiguity, we fitted a plane to the relocated hypocenters. We performed the fitting in a weighted least-squares sense, using weights according to the horizontal and vertical location errors. The relocated hypocenters are aligned with a North-South-striking, steeply Eastdipping plane, with the strike and dip of $356.26^{\circ}$ (331.15, $19.99^{\circ}$; with $95 \%$ confidence) and $65.56^{\circ}$ $\left(62.47^{\circ}, 69.85^{\circ}\right.$; with $95 \%$ confidence), respectively. The aftershocks are gathered to a narrow band, suggesting that the seismic activity is restricted only to a patch of the fault plane, therefore the fitting results should be handled carefully. The clustered nature of the earthquakes along the fault may be caused by stress concentrations due to asperities or changes in rheology (Waldhauser et al. 2004), inducing seismic slip. We conclude that the fault is most likely North-South-striking, but the east-west direction could also not be ruled out. 


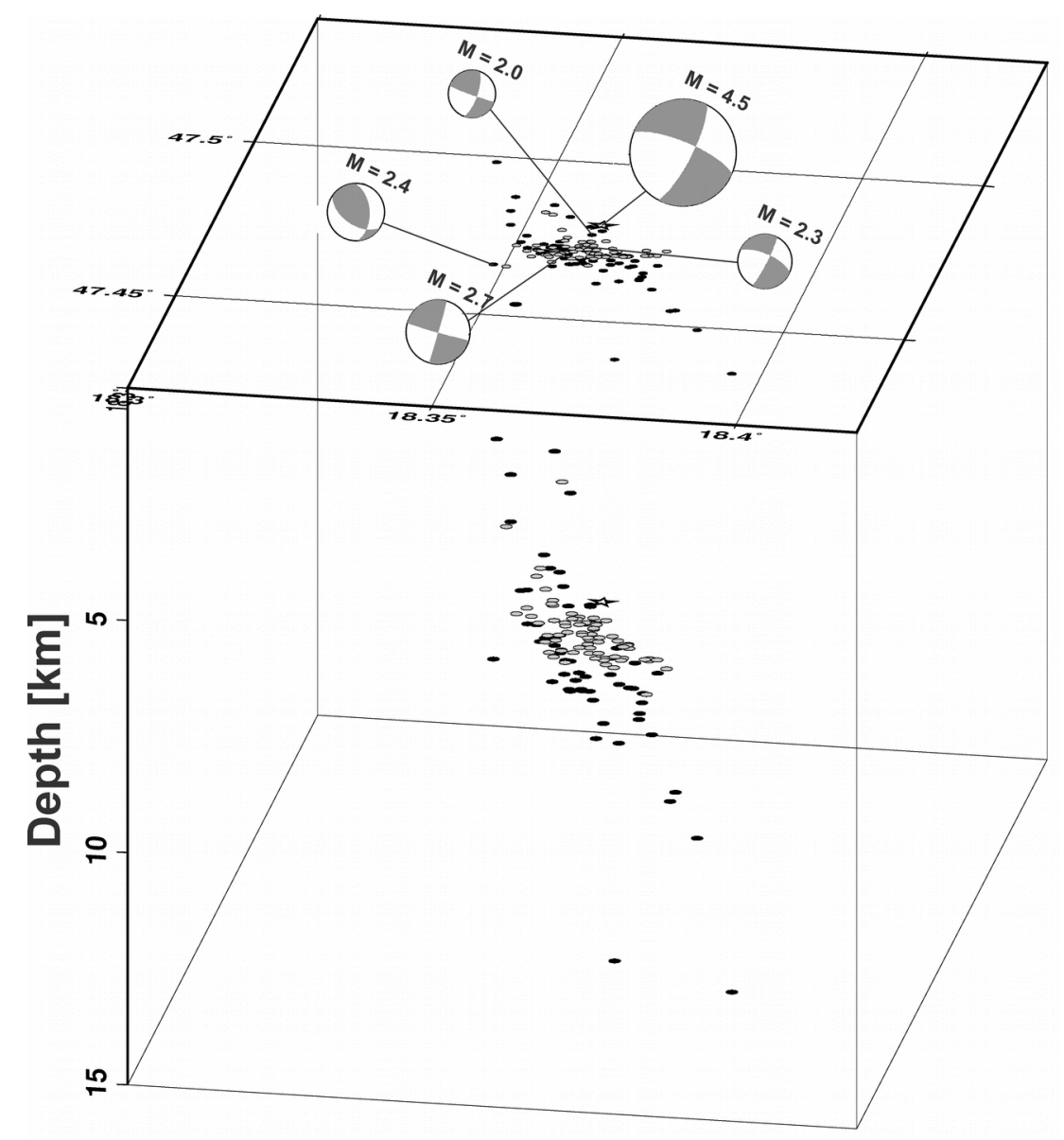

Figure 4. 3D map of the relocated hypocenters and focal mechanism solutions of the mainshock and four aftershocks (Wéber and Süle 2014).

The relocated epicenters and the surface projection of the fitted plane are plotted to the schematic geological map of the study area (Figure 7, after Budai and Fodor 2008) to compare our results with the mapped faults. The aftershock sequence is located at the western foreland of the Vértes Hills, Southeastern to the town of Oroszlány. The epicenters cannot be directly related to surface faulting. Taking into consideration the fault plane geometry, the surface projection of the fault is shifted ca. 3.5 $\mathrm{km}$ towards West relative to the cluster centroid. The N-S striking projected fault line could be followed near a NNW-SSE striking supposed fault of the geological map. It is important to note that the projected fault should be considered only as an approximation of the location of the structure related to the seismicity. 




Figure 5. Epicenters of the earthquakes and the surface projection of the fitted plane (dotted black line) comparison with the mapped faults after Budai and Fodor (2008). The main shock is indicated with white circle. Events occurred before and after the operation of the temporary stations are black and light grey circles, respectively. The supposed fault that might be related to the seismicitiy is outlined with dashed black line.

\section{Rheology of the lithosphere at Oroszlány}

Former studies of the rheology of the lithosphere in the Pannonian-Carpathian-Dinaric region indicated that the internal part characterized by high heat flow density is weak and the strength of the lithosphere is concentrated to the upper crust (Bodri 1996; Lankreijer et al. 1999; Lenkey et al. 2002; Sachsenhofer et al. 1997). It is in agreement with the low to moderate seismicity observed in the Pannonian basin (Tóth et al. 2008), and the distribution of the focal depths, which concentrate in the upper crust in the 4-12 km depth range (Zsíros 2000). The accurately determined hypocenters of the aftershocks of the Oroszlány earthquake indicate the brittle part of the crust, which allow the checking of the lithospheric strength profiles calculated for the study area.

The rheological profile of the lithosphere depends on the rock types of the upper and lower crust and the mantle, the geotherm, the deformation rate and the tectonic style of the deformation. We calculated the brittle yield stress using the Byerlee Law and the ductile yield stress assuming powerlaw creep. For the equations see Table 3.. We determined the brittle yield stress only for strike-slip deformation, because the focal mechanism solutions of the Oroszlány earthquakes indicate such tectonic regime (Wéber and Süle 2014). The moderate seismicity 
in the central part of the Pannonian basin (Berhida-Mor-Komarom region) can be explained by the differential northeastern motion of 1-1.3 mm/year (Grenerczy et al. 2000). Assuming that this deformation is distributed over the North Pannonian terrain, which is about $500 \mathrm{~km}$ wide, the resulting deformation rate is $0.7-0.8 \times 10^{-17} 1 / \mathrm{s}$. For simplicity, we used deformation rate of $10^{-16}$ 1/s. The crust and mantle is composed of rocks most frequently used in rheological models: upper crust - dry granite, lower crust - (a) dry diabase, or (b) felsic granulites in the upper part and mafic granulites in the lower part, or (c) mafic granulites, upper mantle - dry dunite (e.g. Cloetingh et al. 2010; Fernandez and Ranalli 1997; Ranalli 1995). The lower crust consists mainly metamorphic granulites. In the Pliocene basaltic tuffs in the Bakony-Balaton Highland Volcanic Field (BBHVF), located $100 \mathrm{~km} \mathrm{SW}$ to Oroszlány, lower crustal mafic granulite xenoliths are present (Dobosi et al. 2003; Török 2014). However, felsic granulites or diabase are also often assumed in rheological models (see above), therefore we tested three scenarios listed above. The material properties of the brittle and ductile deformations of the rocks are given in Table 3.. The crustal thickness at Oroszlány $(30 \mathrm{~km})$ is taken from Lenkey et al. (this volume, Fig. 3b, and references therein). The division between upper (15 km) and lower crust (15 km) is pure assumption due to lack of data. The geotherm is based on thermal modeling. The time dependent temperature field in the lithosphere in the Alpine-Pannonian transition zone, including the present study area, was calculated by 3D numerical modeling (Lenkey et al., this volume). The model was fit to the observed heat flow densities and temperature logs in several wells, therefore we assume that it represents the thermal field of the lithosphere in the area. The temperature until $50 \mathrm{~km}$ depth at Oroszlány is presented in Figure 6.a. The rheological profile corroborates the results of the former studies (Bodri 1996; Lankreijer et al. 1999; Lenkey et al. 2002; Sachsenhofer et al. 1997) that the mantle part of the lithosphere is not able to bear stresses due to the high temperatures in the mantle Figure 6.b. The strength of the crust depends on the composition of the lower crust: in case of dry diabase (a) or felsic granulites in its upper part (b) the stress is accumulated in the upper crust in accordance with the focal depths distribution of the Oroszlány earthquakes. On the contrary mafic granulites (c) result in strong lower crust, which is not supported by the seismological data. We conclude that a three-layer crust consisting of dry granite, felsic granulites and mafic granulites or two layer crust made of dry granite in the upper crust and dry diabase in the lower crust are in agreement with the focal depth distribution at Oroszlány. The results are probably valid for the whole Pannonian basin due to the lack of lower crustal earthquakes.

\begin{tabular}{|c|c|c|c|c|c|c|}
\hline \multicolumn{6}{|c|}{ Parameters of the ductile deformation } & \multirow{3}{*}{$\begin{array}{c}\text { units } \\
\mathrm{km}\end{array}$} \\
\hline Stratification & $\begin{array}{l}\text { upper } \\
\text { crust }\end{array}$ & \multicolumn{3}{|c|}{ lower crust } & $\begin{array}{l}\text { upper } \\
\text { mantle }\end{array}$ & \\
\hline depth & $0-15$ & $15-30^{\mathrm{a}}$ & $15-22.5^{b}$ & $\begin{array}{c}22.5-30^{b}, 15- \\
30^{c} \\
\end{array}$ & $30-50$ & \\
\hline petrology & $\begin{array}{c}\text { dry } \\
\text { granite }^{1,2}\end{array}$ & $\begin{array}{c}\text { dry } \\
\text { diabase }^{1,2}\end{array}$ & $\begin{array}{c}\text { felsic } \\
\text { granulite }^{3} \\
\end{array}$ & $\begin{array}{c}\text { mafic } \\
\text { granulite }^{3} \\
\end{array}$ & $\begin{array}{c}\text { dry } \\
\text { dunite } \\
\text { dur, }\end{array}$ & \\
\hline density $(\rho)$ & 2700 & 2900 & 2900 & 2900 & 3300 & $\mathrm{~kg} \cdot \mathrm{m}^{-3}$ \\
\hline powerlaw exponent (n) & 3.3 & 3.05 & 3.1 & 4.2 & 4.5 & - \\
\hline $\begin{array}{l}\text { powerlaw activation } \\
\text { energy }\left(E_{p}\right)\end{array}$ & 186 & 276 & 243 & 445 & 535 & kJ.mol ${ }^{-1}$ \\
\hline $\begin{array}{ll}\text { powerlaw } & \text { exponential } \\
\text { constant }\left(A_{p}\right) & \\
\end{array}$ & $3.16 \mathrm{E}-26$ & $6.31 \mathrm{E}-20$ & $2.01 \mathrm{E}-21$ & 8.83E-22 & $7.94 \mathrm{E}-18$ & $\mathrm{~Pa}^{-\mathrm{n}} \mathrm{s}^{-1}$ \\
\hline \multicolumn{7}{|c|}{ powerlaw creep: $\sigma_{\text {creep }}=\left(\dot{\varepsilon} / \mathrm{A}_{\mathrm{p}}\right)^{1 / \mathrm{n}} \exp \left(\mathrm{E}_{\mathrm{p}} / \mathrm{nRT}\right)$} \\
\hline universal gas constant (R) & \multicolumn{5}{|c|}{8.314} & ${\mathrm{~J} . \mathrm{mol}^{-1}}^{-1}$ \\
\hline strain rate $\left(\varepsilon^{\prime}\right)$ & \multicolumn{5}{|c|}{$10^{-16}$} & $s^{-1}$ \\
\hline
\end{tabular}




\begin{tabular}{|l|c|c|c|}
\hline Parameters of the brittle deformation & value & units \\
\hline acceleration of gravity & $\mathrm{g}$ & 9.81 & $\mathrm{~m}^{-2}$ \\
\hline densities of the layers are given in the table of ductile parameters & $\rho$ & & $\mathrm{kg} \cdot \mathrm{m}^{-3}$ \\
\hline hydrostatic pore fluid factor & $\lambda$ & 0.36 & - \\
\hline numerical factor for strike slip faulting & $\alpha$ & 1.2 & - \\
\hline \multicolumn{2}{|c|}{} \\
\hline
\end{tabular}

Table 3. Parameters used in calculating the ductile and brittle deformations of the lithosphere (after Carter and Tsenn 1987; Goetze and Evans 1979; Wilks and Carter 1990).

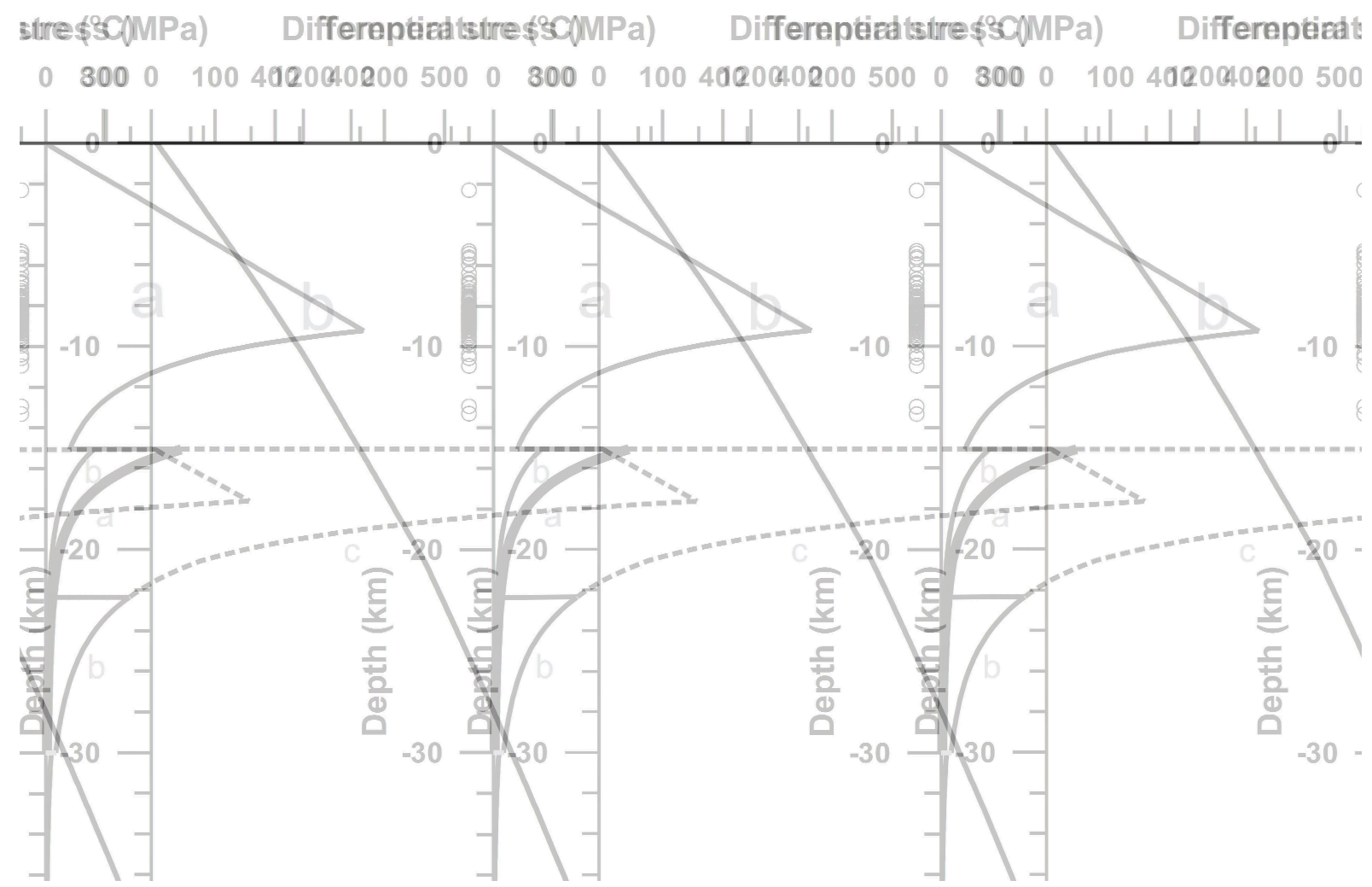

Figure 6. a: Crustal and upper mantle temperature at Oroszlány obtained from the temperature model of the lithosphere in the Alpine-Pannonian tranzition zone (Lenkey et al. this volume). b: Rheological profiles at Oroszlány calculated using the Byerlee Law and the powerlaw with parameters given in the text and Table 3., and temperature shown in a. Profile a: dry diabase, profile b: felsic granulites in the upper part, and mafic granulites in the lower part of the lower crust, profile c: mafic granulites. Circles indicate the focal depths of the aftershocks of the Oroszlány earthquakes shown in Figure 3. and Figure 4..

\section{Discussion and conclusions}

We have relocated the Oroszlány, Hungary aftershock sequence with the double-difference multiple event location method. We first determined the absolute event locations with iLoc using a local 1D velocity model. We applied HypoDD on the iLoc initial locations with the combined use of catalog and cross-correlation differential times.

Our results show that: 
- Bulletin data appear to separate hypocenters to two clusters on the cross-sections, but iLoc relocations suggest and the multiple event location results confirm that it is an artifact due to missing two temporary stations in the first two days of the aftershock sequence.

- Significant improvement in the picture of seismicity is gained with the double-difference relocations: the cluster becomes tighter both on map view and cross-sections.

- The relocated hypocenters suggest N-S striking, steeply eastward dipping fault plane, in agreement with the N-S striking nodal plane of moment tensor solutions.

- Since the iLoc cluster contains 7 GT5 events, and the spatial offset of the GT events obtained with iLoc and HypoDD is less than $5 \mathrm{~km}$, the entire cluster can be promoted to GT5.

Earthquake hypocenter determination becomes more accurate by applying multiple event location techniques, but a dense seismic network is crucial for the relocation process to monitor small magnitude earthquakes. The deployment of the AlpArray seismic stations in the Transdanubian Range significantly improves the station coverage and would allow high-resolution earthquake monitoring in the future. Location accuracy could also be improved by adapting 3D velocity models, but currently no local 3D models are avaliable for the staudy area.

At the study area the focal depths of earthquakes, the tectonic regime, the geotherm and the deformation rate are well constrained. They allow the determination of the lithospheric strength with high reliability. The appropriate knowledge of the lithospheric strength is crucial to assess the probability of induced earthquakes when EGS are developed, thus similar calculations contribute to locate potential safe EGS sites.

\section{Acknowledgements}

This study was supported by the Kövesligethy Radó Seismological Observatory, providing all efforts and data for our research project. We are grateful to the Georisk Ltd. for the waveforms recorded by the Paks Microseismic Monitoring Network. 


\section{References}

Bada G, Horváth F, Dövényi P, Szafián P, Windhoffer G, Cloetingh S (2007) Present-day stress field and tectonic inversion in the Pannonian basin Global and Planetary Change 58:165-180

Bodri B (1996) Thermal state, rheology and seismicity in the Pannonian basin, Hungary Journal of Geodynamics 21:309-328

Bondár I, McLaughlin K (2009) Seismic location bias and uncertainty in the presence of correlated and non-Gaussian travel-time errors Bulletin of the Seismological Society of America 99:172-193

Bondár I, Myers SC, Engdahl ER, Bergman EA (2004) Epicentre accuracy based on seismic network criteria Geophysical Journal International 156:483-496

Bondár I, Storchak D (2011) Improved location procedures at the International Seismological Centre Geophysical Journal International 186:1220-1244

Budai T, Fodor L (2008) Geology of the Vértes Hills Explanatory book to the geological map of the Vértes Hills (1: 50 000) Regional map series of Hungary Geological Institute of Hungary, Budapest

Carter NL, Tsenn MC (1987) Flow properties of continental lithosphere Tectonophysics 136:27-63

Cloetingh S et al. (2010) Lithosphere tectonics and thermo-mechanical properties: An integrated modelling approach for Enhanced Geothermal Systems exploration in Europe Earth-Science Reviews 102:159-206

Dobosi G, Kempton PD, Downes H, Embey-Isztin A, Thirlwall M, Greenwood P (2003) Lower crustal granulite xenoliths from the Pannonian Basin, Hungary, Part 2: Sr-Nd$\mathrm{Pb}-\mathrm{Hf}$ and $\mathrm{O}$ isotope evidence for formation of continental lower crust by tectonic emplacement of oceanic crust Contributions to Mineralogy and Petrology 144:671-683

Fernandez M, Ranalli G (1997) The role of rheology in extensional basin formation modelling Tectonophysics 282:129-145

Fodor L et al. (2005) An outline of neotectonic structures and morphotectonics of the western and central Pannonian Basin Tectonophysics 410:15-41

Goetze C, Evans B (1979) Stress and temperature in the bending lithosphere as constrained by experimental rock mechanics Geophysical Journal International 59:463-478

Gráczer Z, Wéber Z (2012) One-dimensional P-wave velocity model for the territory of Hungary from local earthquake data Acta Geodaetica et Geophysica Hungarica 47:344357

Grenerczy G, Kenyeres A, Fejes I (2000) Present crustal movement and strain distribution in Central Europe inferred from GPS measurements Journal of Geophysical Research: Solid Earth 105:21835-21846

Kövesligethy Radó Seismological Observatory (Geodetic and Geophysical Institute RCfAaES, Hungarian Academy of Sciences (MTA CSFK GGI KRSZO)) (1995) Hungarian National Seismological Network Deutsches GeoForschungsZentrum GFZ doi:doi:10.14470/UH028726.

Lankreijer A, Bielik M, Cloetingh S, Majcin D (1999) Rheology predictions across the western Carpathians, Bohemian massif, and the Pannonian basin: implications for tectonic scenarios Tectonics 18:1139-1153

Lenkey L, Dövényi P, Horváth F, Cloetingh S (2002) Geothermics of the Pannonian basin and its bearing on the neotectonics EGU Stephan Mueller Special Publication Series 3:2940

Ranalli G (1995) Rheology of the Earth. Springer Science \& Business Media, 
Sachsenhofer RF, Lankreijer A, Cloetingh S, Ebner F (1997) Subsidence analysis and quantitative basin modelling in the Styrian Basin (Pannonian Basin System, Austria) Tectonophysics 272:175-196

Sambridge MS, Kennett BL (2001) Seismic event location: nonlinear inversion using a neighbourhood algorithm. In: Monitoring the Comprehensive Nuclear-Test-Ban Treaty: Sourse Location. Springer, pp 241-257

Török K, Németh, B., Koller, F. et al. (2014) Evolution of the middle crust beneath the western Pannonian Basin: a xenolith study Miner Petrol doi:108: 33. doi:10.1007/s00710013-0287-1

Tóth L, Mónus P, Bus Z, Györi E (2008) Seismicity of the Pannonian basin. In: Earthquake Monitoring and Seismic Hazard Mitigation in Balkan Countries. Springer, pp 99-110

Tóth L, Mónus P, Zsíros T, Kiszely M (2002) Seismicity in the Pannonian Region Â earthquake data Stephan Mueller Special Publication Series 3:9-28

Waldhauser F, Ellsworth W, Schaff DP, Cole A (2004) Streaks, multiplets, and holes: Highresolution spatio-temporal behavior of Parkfield seismicity Geophysical Research Letters 31

Waldhauser F, Ellsworth WL (2000) A double-difference earthquake location algorithm: Method and application to the northern Hayward fault, California Bulletin of the Seismological Society of America 90:1353-1368

Wéber Z, Süle B (2014) Source properties of the 29 January 2011 ML 4.5 Oroszlány (Hungary) mainshock and its aftershocks Bulletin of the Seismological Society of America 104:113-127

Wilks KR, Carter NL (1990) Rheology of some continental lower crustal rocks Tectonophysics 182:57-77

Zsíros T (2000) Seismicity and Seismic Hazard in the Carpathian Basin Hungarian Earthquake Catalog (456-1995) (in Hungarian), MTA FKK GGKI, Budapest, Hungary 


\section{List of figures}

Figure 1. Map showing the most significant earthquakes occurred in Hungary. The seismically most active Berhida-Mór-Komárom region, where the Oroszlány earthquake (white circle) originated, is outlined with dotted black rectangle.

Figure 2. Seismic stations located in the 3-degree radius (left) and 1-degree radius (right) of the mainshock. Grey triangles are stations used for the multiple event location. Station codes in boxes indicate stations used for HypoDD relocations with catalog dataset (solid black boxes, 23 stations), both catalog and cross-correlation data (dashed black boxes, 8 stations). Black circle indicate the location of Oroszlány earthquake and its aftershocks. Stations where cross-correlation differential times are available are shaded according to the number of cross-correlation observations.

Figure 3. Map views (upper), S-N sections (middle) and W-E sections (bottom) of hypocenters reported in the KRSO bulletin (first column), iLoc relocations (second column), and HypoDD results (third column) on iLoc initial locations. The main shock is indicated with a star. Black and grey circles are events occurred before and after BOKD and VSOM were deployed, respectively....

Figure 4. 3D map of the relocated hypocenters and focal mechanism solutions of the mainshock and four aftershocks (Wéber and Süle 2014).

Figure 5. Epicenters of the earthquakes and the surface projection of the fitted plane (dotted black line) comparison with the mapped faults after Budai and Fodor (2008). The main shock is indicated with white circle. Events occurred before and after the operation of the temporary stations are black and light grey circles, respectively. The supposed fault that might be related to the seismicitiy is outlined with dashed black line.

Figure 6. a: Crustal and upper mantle temperature at Oroszlány obtained from the temperature model of the lithosphere in the Alpine-Pannonian tranzition zone (Lenkey et al. this volume). b: Rheological profiles at Oroszlány calculated using the Byerlee Law and the powerlaw with parameters given in the text and Table 3, and temperature shown in a. Profile a: dry diabase, profile b: felsic granulites in the upper part, and mafic granulites in the lower part of the lower crust, profile c: mafic granulites. Circles indicate the focal depths of the aftershocks of the Oroszlány earthquakes shown in Figure 3and Figure 4.10 